\title{
Karakteristik Hasil Penetasan Puyuh Pedaging Malon dan Jepang Terseleksi Generasi ke Lima
}

\author{
E. Sujana ${ }^{1 \mathrm{a}}$, T. Widjastuti ${ }^{1}$, I. Setiawan ${ }^{1}$, A. Anang ${ }^{1}$ \\ ${ }^{I}$ Fakultas Peternakan Universitas Padjadjaran \\ a email : endangsujana78@yahoo.co.id
}

\begin{abstract}
Abstrak
Penelitian dengan judul Karakteristik Hasil Penetasan Puyuh Pedaging Malon dan Jepang Terseleksi Generasi Ke Lima telah dilaksanakan di Test Farm KVS Majalaya. Tujuan penelitian ini untuk mengetahui dan mengevaluasi hasil penetasan puyuh Pedaging Malon dan Jepang Terseleksi Generasi Ke Lima. Penelitian menggunakan metode deskriptif kuantitatif. Analisis deskriptif kuantitatif dilakukan terhadap ukuran pemusatan yaitu nilai rata-rata dan ukuran penyebaran yaitu nilai standard deviasi. Telur puyuh yang digunakan percobaan sebanyak 600 butir atau 300 butir setiap galur. Peubah yang diamati adalah fertilitas (\%), daya tetas (\%), kematian embrio (\%) dan bobot tetas. Hasil penelitian menunjukkan bahwa hasil penetasan telur puyuh pedaging Malon dan Jepang Terseleksi Generasi Ke Lima termasuk baik. Hal ini dapat dilihat pada data hasil penelitian bahwa telur tetas yang berasal dari pembibitan puyuh Malon memiliki fertilitas yang tinggi $(95,83 \%)$, daya tetas yang baik $(80,76 \%)$, kematian embrio 19,24\% dan bobot tetas yang tinggi 8,56 $\pm 0,90 \mathrm{~g}$. Selanjutnya hasil penelitian bahwa telur tetas yang berasal dari pembibitan puyuh Jepang Terseleksi memiliki fertilitas yang tinggi $(96,67 \%)$, daya tetas yang baik $(82,73 \%)$, kematian embrio $17,27 \%$ dan bobot tetas yang tinggi 8,52 $\pm 0,695 \mathrm{~g}$.
\end{abstract}

Kata kunci : Penetasan, Puyuh Pedaging, Malon, Jepang Terseleksi

\section{Characteristics of The Results Hatching Of Malon and Japanese Selected Quails Generation To Five}

\begin{abstract}
Research with the title of the Five Characteristics of Results of the Five Generation Selected Malon and Japanese Quail Hatching was carried out at KVS Majalaya Test Farm. The purpose of this study was to find out and evaluate the results of the fifth generation selected Malon and Japanese Quail hatchery. Research uses quantitative descriptive methods. Quantitative descriptive analysis is carried out on the concentration size, namely the average value and the size of the spread, namely the standard deviation value. Quail eggs used as much as 600 grains or 300 grains per line. The variables observed were fertility $(\%)$, hatchability (\%), embryo mortality (\%) and hatching weight. The results showed that the results of the fifth generation selected Malon and Japanese Broiler quail hatching eggs were good. This can be seen from the research data that hatching eggs from Malon quail nurseries have high fertility $(95.83 \%)$, good hatchability $(80.76 \%$ ), embryo death $19.24 \%$ and high hatching weight $8.56 \pm 0.90 \mathrm{~g}$. Furthermore, the results of research that hatching eggs from selected Japanese quail nurseries have high fertility (96.67\%), good hatchability (82.73\%), embryonic death $17.27 \%$ and high hatching weight $8.52 \pm 0.695$ $\mathrm{g}$.
\end{abstract}

Keywords: Hatching, Meet Quail, Malon, Selected Japanese

\section{Pendahuluan}

Peningkatan konsumsi daging di Indonesia disebabkan oleh meningkatnya kesadaran masyarakat terhadap pentingnya pemenuhan protein hewani. Selama ini, jenis unggas yang berkontribusi besar menghasilkan daging adalah ayam, sedangkan puyuh belum banyak berkontribusi padahal daging puyuh memiliki potensi sebagai penghasil protein hewani yang relative terjangkau masyarakat. Jenis puyuh yang banyak dibudidayakan di Indonesia adalah puyuh Jepang dengan tujuan utama pemeliharaan untuk menghasilkan telur, adapun dagingnya dijadikan produk sampingan 
dari puyuh jantan hasil tetasan yang tidak digunakan untuk bibit dan puyuh betina afkir yang sudah tidak produktif. Ukuran dan bobot karkas kecil menjadi kendala dalam pengembangannya kearah penghasil daging.

Dewasa ini mulai dikembangkan jenis puyuh pedaging yang dikembangkan masyarakat diantaranya puyuh Malon (Manuk londo) dan Jepang (Coturnix-coturnix japonica) terseleksi yang diarahkan ke padaging. Puyuh ini memiliki bobot tubuh lebih besar dari pada puyuh Jepang sehingga lebih potensial dijadikan sebagai penghasil daging. Walaupun populasinya masih terbatas, namun jenis puyuh ini cukup potensial dijadikan sebagai puyuh pedaging, karena memiliki bobot tubuh lebih besar.

Upaya yang perlu dilakukan untuk pengembangan puyuh adalah dengan program pemuliaan dan pemeliharaan secara intensif sehingga menghasilkan produksi dan bibit yang maksimal. Program pemulian dilakukan untuk menghasilkan perbaikan mutu genetik puyuh yang baik yang seperti diharapkan, serta terhindar dari inbreeding yang berdampak pada rendahnya pertumbuhan dan produksi. Program pemeliharaan perlu dilakukan dengan benar dimulai dari pembibitan, penetasan telur dan pemeliharaan mulai anak puyuh sampai diafkir.

Penetasan menggunakan mesin tetas merupakan salah satu teknologi dalam upaya mempercepat perkembangan pupulasi puyuh dengan memperhatikan karakterisasi hasil tetas (fertilitas, kematian embrio, daya tetas dan bobot tetas). Kualitas hasil tetas telur akan menentukan kualitas bibit yang dihasilkan pada generasi selanjutnya baik dari sisi pertumbuhan maupun produksi telurnya. Berdasarkan uraian di atas penulis tertarik untuk melakukan penelitian dengan judul "Karakteristik Hasil Penetasan Puyuh Pedaging Malon dan Jepang Terseleksi Generasi Ke Lima”.

\section{MATERI DAN METODA Materi Penelitian}

Penelitian menggunakan 600 butir telur tetas puyuh, atau masing-masing sebanyak 300 butir telur tetas dari tiap jenis puyuh puyuh. Dua mesin tetas digunakan dengan system manual, di lengkap dengan perlengkapan serta bahan-bahan fumigasi (formalin dan $\mathrm{KmnO} 4$ ). Selanjutnya untuk penimbangan digunakan timbangan digital.

\section{Metode Penelitian \\ Penetasan Telur}

Sebelum telur didistribusikan ke dalam mesin tetas, masing-masing mesin tetas di sanitasi dan di setting agar suhunya konstan (101-102 $\left.{ }^{\circ} \mathrm{F}\right)$ dan kelembaban (70\%). Penetasan diawali dengan memasukkan telur dan ditempatkan pada rak yang sudah disediakan menggunakan 1 mesin tetas. Mulai hari penetasan ke 3 telur diputar 3 kali sehari dan pada hari ke 14 pemutaran telur dihentikan. Hari ke 18 penetasan berakhir. Di akhir penetasan telur-telur yang tidak menetas dipecah untuk melihat adanya tidaknya embrio yang mati dan mengetahui fertil tidaknya telur yang ditetaskan.

\section{Peubah yang diamati}
a. Fertilitas telur (\%)
b. Daya tetas (\%)
c. Kematian Embrio (\%)
d. Bobot Tetas (gram)

\section{Analisis Statistik}

Pengolahan data dilakukan dengan analisis statistika deskriptif terhadap populasi telur tetas dan bobot tetas puyuh menggunakan rumus Sudjana (2005) sebagai berikut :

1. Rata-rata

Data kuantitatif dihitung dengan cara membagi jumlah nilai data oleh banyaknya data.

$$
\bar{x}=\frac{\sum_{i=1}^{N} x i}{N}
$$

$$
\begin{array}{ll}
\text { Keterangan : } & \bar{x} \quad=\text { Rata }- \text { rata } \\
& \sum_{i=1}^{N} x i=\text { Jumlah }
\end{array}
$$

seluruh data

2. Simpangan Baku atau Standar Deviasi Simpangan baku adalah akar ragam. Ragam merupakan jumlah kuadrat semua deviasi nilai-nilai individu terhadap rata - rata populasi, rumusnya adalah :

$$
\mathrm{S}=\sqrt{\frac{\sum_{i=1}^{n}\left(x_{i}-\bar{x}\right)^{2}}{n-1}}
$$

$\begin{array}{lll}\text { Keterangan : } & \text { S } & =\text { Simpangan } \\ \text { Baku } & & \\ \text { ke-i } & x_{i} & =\text { Nilai data } \\ & \bar{x} & =\text { Rata }- \text { rata } \\ & n & =\text { Banyak data }\end{array}$




\section{Hasil dan Pembahasan Fertilitas}

Hasil pengamatan terhadap karakteristik hasil tetas puyuh Malon dan Jepang Terseleksi dapat dilihat pada Tabel 1. Fertilitas merupakan persentase telur yang fertil dari seluruh telur yang digunakan dalam suatu periode penetasan. Perhitungan telur yang fertile dan infertil dengan cara memecahkan telur-telur yang tidak menetas di akhir periode penetasan. Fertilitas dihitung dengan dengan cara membagi jumlah telur yang fertil dengan jumlah telur yang ditetaskan dikali 100 persen.

Berdasarkan Tabel 1 didapatkan fertilitas telur puyuh yang hampir sama yaitu sebesar 95,83 persen pada puyuh Malon dan 96,67 persen pada puyuh Jepang terseleksi. Hasil tersebut menunjukkan angka fertilitas yang tinggi, sejalan dengan pendapat Listiyowati dan Roospitasari (2005), pada kondisi normal dengan sex ratio dan pemberian ransum yang baik puyuh menghasilkan fertilitas sebesar $85-95 \%$ bahkan lebih baik dari hasil penelitian Kaharuddin dan Kususiyah (2006) bahwa fertilitas telur puyuh yang dianggap baik adalah sekitar 68-78\%.

Faktor yang mempengaruhi fertilitas telur diantaranya rasio perbandingan jantan dan betina. Rasio perbandingan jantan-betina adalah faktor yang sangat penting karena berhubungan langsung dengan proses perkawinan. Sex ratio Seks rasio yang digunakan pada penelitian ini dengan perbandingan 1 jantan : 3 betina. Perbandingan jantan betina tersebut memberikan hasil terhadap angka fertilitas yang cukup tinggi, karena dimungkinkan puyuh jantan mampu mengawini hampir seluruh puyuh betina.

Faktor lain yang mempengaruhi fertilitas antara lain adalah nutrien, motilitas sperma, dan persentase sel sperma yang abnormal atau mati. Faktor nutrien misalnya kekurangan mineral atau vitamin $\mathrm{E}$ dalam pakan dapat menyebabkan telur menjadi tidak fertil (King'ori, 2011). Sedangkan bobot telur tidak berpengaruh terhadap fertilitas dan daya tetas tetapi berpengaruh terhadap bobot tetas (Dewanti $d k k ., 2014)$.

\section{Daya Tetas}

Daya tetas adalah jumlah telur yang menetas dibagi dengan jumlah telur yang fertil dikali $100 \%$. Hasil penelitian diperoleh daya tetas puyuh Malon sebesar 80,76\% dan puyuh Jepang terseleksi $82,73 \%$. Hasil penelitian ini menunjukkan bahwa daya tetas telur puyuh cukup baik, sesuai pernyataan Suleyman dkk., (2009) daya tetas puyuh yang baik berkisar 75$86 \%$. Umur Induk yang digunakan berumur 4 bulan, mengacu pada Sugiharto (2005) pengambilan telur tetas puyuh dilaksanakan sejak induk berumur 2,5 - 8 bulan. Lama penyimpanan telur tetas yang menjadi objek penelitian adalah selama 4 hari. Penyimpanan telur tetas 1-5 hari akan mendapatkan daya tetas yang optimal karena menurut Mulyantini (2014), daya tetas lebih dari 5 hari akan menurunkan kualitas telur dan daya tetas.

Tinggi rendahnya daya tetas dapat dipengaruhi oleh suhu dan kelembaban selama proses penetasan karena berpengaruh pada perkembangan embrio. Rata-rata suhu dan kelembaban mesin tetas selama penelitian adalah $101,04{ }^{\circ} \mathrm{F}$ dan $65,21 \%$. Suhu dan kelembaban optimal dapat mendukung perkembangan embrio menjadi maksimal karena suhu yang terlalu tinggi ataupun terlalu rendah dapat mengakibatkan mortalitas embrio meningkat dan telur tidak menetas. Suhu dan kelembaban selama penelitian memenuhi suhu dan kelembaban yang dibutuhkan mesin tetas still air machine yaitu $101,75^{\circ} \mathrm{F}-103{ }^{\circ} \mathrm{F}$ dengan kelembaban puyuh minggu pertama $55 \%-70 \%$ (Paimin, 2011).

Tabel 1. Hasil Pengamatan Karakteristik Hasil Tetas Puyuh Malon dan Jepang Terseleksi

\begin{tabular}{|c|c|c|c|c|}
\hline \multirow{3}{*}{$\begin{array}{l}\text { Peubah } \\
\text { yang diamati }\end{array}$} & \multicolumn{4}{|c|}{ Jenis puyuh } \\
\hline & \multicolumn{2}{|c|}{ Malon } & \multicolumn{2}{|c|}{ Jepang Terseleksi } \\
\hline & Rataan & Std & Rataan & Std \\
\hline Fertilitas (\%) & 95,83 & - & 96,67 & - \\
\hline Daya tetas $(\%)$ & 80,76 & - & 82,73 & - \\
\hline Kematian embrio (\%) & 19,24 & - & 17,27 & - \\
\hline Bobot Tetas $(\mathrm{g})$ & 8,56 & 0,90 & 8,52 & 0,695 \\
\hline
\end{tabular}




\section{Kematian Embrio}

Berdasarkan Tabel 1 didapatkan kematian embrio pada puyuh Malon sebesar $19,24 \%$ dan puyuh Jepang terseleksi 17,27\%. Tingkat kematian embrio dipengaruhi oleh perkembangan embrio yang berlangsung sejak telur diproduksi oleh induk hingga menetas. Kematian embrio banyak terjadi dalam keadaan kritis selama waktu penetasan yaitu selama tiga hari pertama dari masa penetasan dan tiga hari sebelum telur puyuh menetas. Embrio tidak mampu berkembang dengan baik, saat kritis itu antara lain pada perubahan posisi pada saat akan menetas, atau saat anak puyuh mematuki kulit kerabang telur untuk menetas, anak puyuh tidak dapat memakai albumen yang tersisa, kegagalan absorbsi yolk sack saat-saat peralihan dari allanthois ke pernapasan dengan paru-paru (Nugroho dan Mayun, 1981). Kondisi lingkungan penetasan berpengaruh terhadap perkembangan embrio, dan berdampak pada tumbuh normal atau matinya embrio. Kondisi suhu yang terlalu tinggi dan perubahan suhu yang drastis dapat mematikan benih atau embrio di dalam telur. Suhu yang ideal untuk penetasan adalah antara $38,3-40,5^{\circ} \mathrm{C}$ dan kelembaban di dalam mesin tetas antara $60-70 \%$. Pada suhu penetasan $32^{\circ}$ $\mathrm{C}\left(90^{\circ} \mathrm{F}\right)$ untuk waktu $3-4$ jam dapat memperlambat perkembangan embrio di dalam telur. Pada puyuh, kelembaban yang tinggi dapat menyebabkan kesulitan untuk memecahkan kulit telur, walaupun dapat dipecahkan anak puyuh tetap berada dalam telur dan dapat mati dalam cairan telur. Kelembaban yang terlalu tinggi dapat mencegah penguapan air dari dalam telur sehingga sulit dalam memecahkan telur (Imanah dan Maryam, 1992).

\section{Bobot Tetas}

Bobot tetas adalah bobot DOQ setelah menetas yang bulu badannya telah kering dan sebelum diberi makan atau minum (satuan gram). Nilai bobot tetas kemudian dihitung berupa rata-rata dan simpangan baku. Hasil perhitungan bobot tetas yang disajikan pada Tabel 1, diperoleh puyuh Malon sebesar 8,56 $\pm 0,90 \mathrm{~g}$ dan Jepang terseleksi 8,52 $\pm 0,695 \mathrm{~g}$. Bobot tetas dipengaruhi oleh bobot telur, hal ini dikarenakan jika bobot telur besar maka bobot tetas yang dihasilkan juga besar, begitu juga sebaliknya. Hal ini sesuai dengan penelitian Sujana, dkk. (2011) menyebutkan bahwa bobot telur berpengaruh terhadap bobot tetas. Semakin besar bobot telur maka bobot DOQ yang dihasilkan akan besar pula. Telur puyuh dengan bobot 12 gram menghasilkan anak puyuh yang lebih berat dibandingkan telur puyuh berbobot 10 dan 8 gram (Kaharuddin, 1998).

Bobot tetas dapat dipengaruhi oleh faktor genetik dan lingkungan terutama pemeliharaan, bobot induk, dan umur induk yang menghasilkan telur tetas. Induk - induk yang terlalu muda atau tua akan menghasilkan anak unggas yang kecil (Latour dkk., 1998). Umur induk yang terlalu muda akan menghasilkan telur tetas yang lebih kecil. Penggunaan umur induk yang tepat dapat menghasilkan bobot tetas yang baik. Umur induk yang digunakan dalam pembibitan yaitu 2,5-8 bulan (Sugiharto, 2005). Umur induk yang digunakan dalam penelitian ini adalah 4 bulan. Penyimpanan juga berpengaruh terhadap bobot tetas, telur yang disimpan lebih lama akan mempengaruhi bobot tetas dan juga berdampak pada peningkatan jumlah kematian embrio (Mulyantini, 2014).

Bobot tetas juga dipengaruhi oleh suhu dan kelembaban mesin tetas. Suhu diatas optimum akan menghasilkan anak unggas yang lebih kecil karena dehidrasi, sedangkan kelembaban yang terlalu tinggi akan menghasilkan anak ayam yang lebih berat dan lembek pada daerah abdomen (Gunawan, 2001). Anak puyuh yang menetas pada kelembaban pengeraman $55 \%$ nyata lebih berat dibandingkan yang menetas pada kelembaban $45 \%$. Selain suhu dan kelembaban pada mesin bobot tetas juga dipengaruhi oleh umur induknya (Hamdy dkk., 1991).

\section{Kesimpulan}

Karakteristik hasil tetas puyuh Malon dan Jepang terseleksi Generasi Ke Lima termasuk baik. Hal ini didukung dari penelitian puyuh Malon memiliki fertilitas yang tinggi $(95,83 \%)$, daya tetas yang baik $(80,76 \%)$, kematian embrio $19,24 \%$ dan bobot tetas yang tinggi $8,56 \pm 0,90 \mathrm{~g}$. Selanjutnya hasil penelitian puyuh Jepang Terseleksi memiliki fertilitas yang tinggi $(96,67 \%)$, daya tetas yang baik $(82,73 \%)$, kematian embrio $17,27 \%$ dan bobot tetas yang tinggi $8,52 \pm 0,695 \mathrm{~g}$. 


\section{Daftar Pustaka}

Dewanti, R., Yuhan, dan Sudiyono. (2014). Pengaruh bobot dan frekuensi pemutaran telur terhadap fertilitas, Daya tetas, dan bobot tetas itik lokal. king'ori, A. M. 2011.Review of the factors that influence egg fertility and hatchability in Poultry. Int. J. Poult. Sci. 10: 483-492.

Gunawan, H. (2001). Pengaruh Bobot Telur terhadap Daya Tetas serta Hubungan Antara Bobot Telur dan Bobot Tetas Itik Mojosari. Skripsi. Jurusan Ilmu Produksi Ternak. Fakultas Peternakan. Institut Pertanian Bogor.

Hamdy, A.M.M., A.M. Henken, W.V.D. Hel, A.g. Galal and A.K.I. Abd- Elmoty. (1991). Effect of incubation humidity and hatching time on heat tolerance of neonatal chicks : Growth performance after heat exposure. Poultry Science.

Imanah dan Maryam. (1992). Mesin Tetas dan System Pemeliharaan Ayam. C.V. Bahagia, Pekalongan.

Kaharuddin, D. (1998). Pengaruh Bobot Telur Tetas terhadap Bobot Tetas, Daya Tetas, Pertambahan Bobot Badan dan Angka Kematian sampai pada puyuh (Coturnix-coturnix japonica). Laporan Penelitian. Universitas Bengkulu, Bengkulu.

King'ori, A. M. (2011). Review of the factors that influence egg fertility and hatchability in Poultry. Int. J. Poult. Sci. 10: 483-492.
Latour, M.A., E.D. Peebles, S.M. Doyle, T. Pansky, T.W. Smith and C.R Boyle. (1998). Broiler breeder age and dietary fat influence the yolk fatty acid profiles of fresh eggs and newly hatched chicks. Poultry Science

Mulyantini, N. G. A. (2014). Ilmu Manajemen ternak Unggas. Gadjah Mada University Press, Yogyakarta.

Nugroho \&K.T. Mayun, (1981). Beternak Burung Puyuh. Eka Offset, Semarang.

Paimin, F. B. (2011). Mesin Tetas. Penebar Swadaya, Jakarta.

Sujana, E., T. Widjastuti dan A. Anang, (2016). Evaluasi hasil tetas puyuh petelur unggul galur murni warna bulu cokelat, hitam dan silangannya di pusat pembibitan puyuh universitas padjadjaran. Prosiding Seminar Nasional Peternakan Berkelanjutan ke 8. Fakultas Peternakan Universitas Padjadjaran. Bandung

Sugiharto, R.E, (2005). Meningkatkan Keuntungan Beternak Puyuh, Agromedia Pustaka, Jakarta.

Suleyman, D., S. Inal, T. Caglayan, M. Garip, and M Tilki. (2009). The effects of parent age, egg weight, storage length and temperature on fertilty and hatchability of japanese quail (Coturnix-coturnix japonica) eggs. http://medwelljournals.com. 